tions are impeded by the hardness of the skull, and especially by the cerebro-spinal fluid, and there is therefore a reciprocity between the amount of blood and that of the fluid which causes variations of pressure in the latter. The favourable results obtained from lumbar puncture by Salmon in the treatment of intense headache accompanied by disturbance of vision induced Professor Mingazzini to apply this method to those forms of permanent headache which are so frequent, especially in young women.

The patients, six men and 41 women, were kept under observation for several months, some even for two or three years. T'hey were all selected, uncomplicated cases, care being taken to eliminate any suspected of syphilis or tubercle, chronic nephritis, or intoxication by tobacco or alcohol, epilepsy or incipient tumour, a searching examination of the fundus oculi being insisted upon in every instance. The results of analysis of the fluid were invariably vormal, all trace of globulin being absent, lymphocytes were either not present or did not exceed 2-3, while the albumin Was in normal quantity as shown by Nissl's test. In almost all the patients there was a distinct increase of the headache after the puncture, sometimes lasting 8-10 days; rarely the pain disappeared immediately after puncture; while in one case only was there first a remission and then an exacerbation. The results of the puncture were not always the same: a definite cure was obtained in 24, about half the cases; a distinct improvement in 15 , in whom the pain was so mitigated as to be more than bearable or returned after a long interval. In 8 cases no benefit was obtained. The result, favourable or otherwise, did not seem to depend on the age of the patient at the time; thus in one woman, aged 60 years, who had been subject from her youth to frequent attacks of headache, which for about six months had become of daily occurrence, a definite cure was obtained from a single puncture, while in another patient of 22 years, who had suffered for two years from headache after typhoid fever. no benefit resulted. In the unbenefited cases the pressure of the cerebro-spinal fluid was normal or low, whereas in those where there was improvement it was always high, indicating that increased pressure must be considered as one of the indubitable factors of the complaint. There seemed to be no connexion, however, between the quantity of fluid drawn off and the result obtained; in fact, in several patients who got no relief as much as 15 to 30 c.c. were drawn off, whereas in some who were relieved or cured 10 or even 5 c.c. were sufficient.

It might be thought that in cases where there - was merely some improvement a complete cure would be obtained from a second puncture, but this only rarely happens, and some cases have derived no benefit even from repeated puncture. The reason for these different results is by no means clear, but, as a general rule, it may be stated that when the first attacks have begun early in life and the headache has become permanent later on without appreciable cause, the result of puncture has been a cure, or at least an improvement. No improvement, on the contrary, takes place in women in whom the headache had either been permanent from the beginning, or had commenced by attacks after the age of 20 , and become permanent from debilitating causes, such as suckling or long illness, or else was associated with other neuroses, such as neuralgia of the fifth nerve, polio-encephalitis and epilepsy. Those cases which improved after puncture had generally suffered from permanent headache for a few months, whereas in patients in whom no benefit resulted the headache had been permanent for more than a year. Hence a permanent headache of long duration seems to be an element unfavourable for cure by puncture, but the changing of the headache from a paroxysmal to a permanent form, a commencement in the second decade of life without appreciable cause, and a duration of permanent headache for less than a year, represent elements favourable to the success of lumbar puncture.

\section{THE BIOLOGICAL ASPECTS OF WARFARE.}

By Harry Campbetu, M.D. Lond., F.R.C.P. Lond., PHYSICIAN TO THE WEST-END HOSPITAL FOR NERVOUS DISEASES, LONDON

\section{II. (Concluded).*}

The Checks to the Operation of Might.

IT will be observed that the checks on the operation of egoistic might which we have already considered are purely intra-communal, their sole object being the integrity of the community. In the earlier phases of human society they took no part in regulating the relations between separate communities-between family and family or between tribe and tribe. The concern of each unit was its own welfare alone. It did not in the least trouble itself about the welfare of other communities. Oonsequently the principles which regulated the conduct of the members of any one community among themselves in no way governed their conduct towards other communities. The code of morality within the community did not obtain between individual communities. Rather was there a tendency for separate communities to regard one another with suspicion and animosity, so that incessant inter-tribal warfare may be said to have been the normal condition during the tribal phase of man's history. The more one tribe could injure its neighbours by murder, pillage, and the like, the more did it aggrandise itself, just as the status of the young brave was raised as the number of scalps he could display increased. In short, the sanction of conduct obtaining between separate communities was just that of might pure and simple. But with the further development of society - with the establishment of nations having commercial relations with one another--agreements of some sort had to be entered into between them, and these international obligations have become more and more binding as civilisation has advanced.

Now it might be thought that with the growth of com-. mercialism, and the increasingly intimate social relations. between separate states rendered possible by the evergrowing facilities of intercourse and transit, those checks to the operation of the might sanction which obtain within, and secure the cohesion of, individual states would in like manner gradually come to unite the nations of the world in one all-embracing commonwealth; and that just as within the properly ordered state conduct is guided and conflicting. interests-personal, social, political, religious-reconciled, on lines of justice and common-sense, so also could, and should, international conduct be governed and international disputes be adjusted. But this devoutly-to-be-wished-for consummation is not yet. We have recently seen how a nation may in its dealings with other nations cast aside all moral restraints and revert to the same sanction of might as obtained between the most primitive human communities.

There could be no greater contrast than that between the ethical standard prevailing within a State and that obtaining between States at war with one another. In the one case the motto is, "Let justice be done though the heavens fall"; in the other justice is cast to the winds and the issues are to be decided by might alone. In the one case so high is the value set on life that every opportunity is afforded even to the most atrocious. murderer to prove that he is innocent; in the other wholesale slaughter by the most terrible means which the mind of man can devise is sanctioned. In the one case the sanctity of private property and of compacts is rigorously upheld by all the might and majesty of the law; in the other compacts are dishonoured and property destroyed or confiscated to the value of untold millions on the sole ground of military necessity. All this is strangely primitive. When the citizens of a well-ordered State have a dispute over conflicting interests, private or social, they appeal to justice, and were anyone to suggest that the issue should be decided by personal combat his sanity would be suspected; but when a dispute arises between two nations and they fail to adjust it by argument it but rarely happens that they mutually agree-especially if the one be more powerful than the other-to subrait to arbitration; they appeal instead-they revert-to the age-old sanction of might.

Article I. and the first part of Article II. were published in THE LANCET of Sept. 15th (p. 433) and Sept. 22nd (p. 469) respectively. 
The Influence of Warfare in Moulding the Individual.

In considering the effects of warfare on mankind we must distinguish between its educative effects, i.e., its influence in moulding the individual, and its racial effects, i.e., its influence in mouldıng the race. As regards the latter, I have already endeavoured to show that, while primitive intertribal warfare operated eugenically by favouring a survival of superior types, modern warfare operates dysgenically by promoting the survival of inferior types. But while mudern warfare is thus raoially harmful, individually warfare has always had some educational value, and it would be idle to shut our ejes to the fact. It is remarkable that among primitive communities those which cultivate warfare are generally superior to those leading peaceful lives. It may be argued that they become warlike because they are superior rather than the reverse. Facts, however, tend to show that whether a community is warlike or peaceful depends mainly upon the conditions under which it lives; thus the nomadic career of the hunter and herdsman is favourable to the warlike spirit, while the life of "stationary" (as distinguished from "migratory") agriculture tends to be peaceful.

There can be no doubt that military training has a beneficial influence, physical and mental, in moulding the individual. Its good effect physically is shown in the rapid improvement in the physique of recruits after enlistment. (At the outbreak of the present war there were far too many contracted chests and round shoulders in this country.) Its value in the moulding of character is no less decided; above all, it teaches discipline and respect for authority, bosh of which are in danger of neglect in democratic communities. It would be difficult to exaggerate the importance of discipline: it is a prime essential to good citizenship, and it is as needful to the one sex as the other. Every boy and every girl should from an early age come under its rigorous influence and be made to realise not only that it is an essential to right living, but also to individual happiness and success in life ; and there is nothing better calculated to inculcate discipline than military training. This, or something equivalent to it, should begin in early school life.

So much for the good that can be got from training for war. What about war itself? While realising that man has evolved through slaughter, and that every step in his long upward path has been stained with blood, I must confess that modern warfare seems to me as inane as it is horrible. This wholesale slaughter and mutilation of one set of men by another set of men who have no personal quarrel with one another, who are not oven personally known to one another, and who under different circumstances might have been knit together in closest fellowship, has for me no bright side. This driving of thousands upon thousands of a nation's picked manhood to the shambles, this wanton carnage, to say nothing of the loss of productive energy and the colossal destruction of wealth, is, one feels instinctively, wrong; the horror is only equalled by the inanity of it.

But though actual war is detestable, yet it must be confessed that indirectly it serves a useful purpose in that the fear of it leads a nation to exercise itself in the virile pursuit of arms and to hold itself in readiness to meet an enemy, while actual war rouses the community to put forth supreme efforts; and this striving to overcome a threatened or actual danger works beneficially and leads to the development of latent possibilities in a manner undreamt of in the easygoing times of peace.

Nothing but the call of actual war could have aroused our country to accomplish what it has accomplished since the July of 1914. What other impelling force could have induced us to increase our national expenditure tenfold, to liberate vast stores of unused energy, to transform the whole economic life of the people, to sacrifice by tens of thousands the flower of our manhood, as has been done since the declaration of the war? All which goes to show how great things a nation can accomplish once the necessary stimulus is forthcoming. If only some equally effective stimulus could be found in times of peace, one which should impel to similar energetic action, not for the purpose of slaughter and destruction, but for the common good! What might not be accomplished if all the euergy and ingenuity and self-sacrifice which we have devoted to the prosecution of this war had been directed to the clearing out of the slums of our cities and to the providing for the toiling millions healthy, well-appointed, and beautiful homes. Our present experience should serve to bring forcibly before us the fact that we have it in our power to do all this and much more. All that is needed is the proper organisation and distribution of our activities-and the adequate stimulus. But how to get the stimulus is the ditticulty. I fear that nothing but a great external danger such as we are now facing is capable of supplying it Theoretically a great religious revival might suffice, but it would have to be one which concerned itselt not so much with the attainment of a possible heaven in another world as with the removal of some of the evils suggestive of another place in this one.

Strange as it may seem, and contrary as it may be to our predilections and a priori conceptions, the condition of peaceful ease in which we picture the lion lying down with the lamb is, from nature's point of view, far from the ideal. A community long lulled in a state of blissful ease is bound to deteriorate, for all healthful life implies struggle. Man needs to be roused from the apathy into which he so easily slips by difficulties to overcome, and there is no more arousing stimulus than the apprehension of danger.

Few will deny that when the present world-war burst upon us we had as a nation grown lax and inert through long years of ease and luxury, and that whatever may be said of the ultimate effect of the war on the other helligerents, the people of these islands and of the British Empire as a whole will be greatly benefited by it. For not only has it tightened the bonds which unite the units of the Empire, but it has awakened undreamt-of stores of dormant activity, and I go as far as to believe that the greater the difficulties we may still have to contend with - the tighter the corner in which we may find our. selves, the more we may be compelled to fight with our backs to the wall-the better will it be for us individually and for the Empire at large ; for it is only through struggle, fierce and sustained, that an individual or a nation can realise itself to the full. Struggle has been a necessary factor in evolution. It is the normal condition of every living thing, save those degraded parasites which inhabit the interior of their host and pay the penalty of their parasitism by a corresponding degradation in structure and function; for it is a primal law of nature that once the need for struggle is removed degeneration sets in. Hence one of the great social problems confronting man in the future will be how, without having recourse to war with all its horrors, to countertat the enervating and degenerating effects of the ease and luxury which tend to be shared by a considerable section of every pros. perous community. In the perfect State the conditions would be such as to render such enervation impossible. Every able-bodied person would be compelled to pull his full weight in the ship of State-to play his part in that healthful struggle which is essential to adequate development. Pure parasitism, which prevails all too widely among us, would be debarred save in the case of the diseased and decrepid. To sanction it is unjust to the individual, though be may not know it, and unjust to the State. (In insisting upon struggle as essential to development, individual and national, I do not, of course, mean that it should be so severe as to be paralysing. No one would contend, e-g., that conditions of abject poverty can have any other than evil results.)

If $I$ am asked how a nation, once peace and prosperity are secured to it, is to be kept engaged in bracing struggle and prevented from lapsing into enervating ease, I reply that I have no panacea. This desirable end can only come through enlightenment. But while so many evils to be set right still remain within the body-politic, while so many social questions of the gravest rurgency press increasingly upon us, while all Europe has to be rebuilded and its new world relations to be readjusted. it is safe to say that it will be long years before we shall be in any danger of relapsing into dreamful ease and before that time comes the enlightenment may have come also. Moreover.

$$
\begin{aligned}
& \text { W... Man is not man as yet. } \\
& \text { Equal an mankind allike is perfected, } \\
& \text {...... begins maun powers - general infancy. }
\end{aligned}
$$$$
\text { Means of Preventing Warfare. }
$$

Whether the nations of the world will ever attain to sufficient wisdom to abandon warfare I forbear to prophesy. One cannot but hope that with advancing knowledge and clearer vision war will tend to die out, and that just as we in this country, after centuries of internecine fighting, were finally welded into a united people, so all the nations of the 
earth will some day be united into one great commonwealth. We are living in great times. Vast regions of the world are being opened up and developed with stupendous zeal; the exuberant output of inventions, such as the telephone, the automobile, the flying machine, and labour-saving machinery of all kinds, is profoundly modifying the conditions of life; intercourse between nations is becoming more and more intimate, added to which men are gaining an ever deeper insight into the laws of life; the elemental facts of evolution, of heredity, and of social science are beginning to make serious appeal to men's minds, and must before long be accepted as axiomatic truths pregnant with meaning as regards human welfare. The time is not far distant when children will be taught these truths as they were once taught their catechism, so that they will become part and parcel of the common mental equipment, and when this stage of general enlightenment is reached nations, it may be hoped, will find other ways of settling their disputes than by an appeal to the barbaric sanction of might.

When the unhappy Malvolio complained of the darkness of his cell, the fool's taunt was, "There is no darkness but ignorance." It was Malvolio's entire ignorance of the true situation which led him to think that his mistress had lost her heart to him, and in like manner it was the darkness of ignorance which is responsible for the present European cataclysm, ignorance alike of the elemental principles of sociology and current European politics. Does anyone for one moment suppose that the masses of the Central Empires would have entered upon the present struggle so light-heartedly if they had understood the actual situation as the author of "J'Accuse" e.g., understands it? Or if they had realised that hundreds of thousands of their numbers were to be slaughtered and broken without any resultant advantage to the survivors? Again, was it not ignorance-tragic ignorance-on the part of their rulers which allowed them to force on the war? They miscalculated, they displayed stupidity-they lacked enlightenment. Had they known the forces they wore stirring up against themselves, we may be quite sure they would not have been guilty of what must ever rank as one of the greatest crimes in history.

A factor which we may reasonably hope will tend to make wars less frequent is the growth of democracy. The trend of political development among the most enlightened nations is towards a moderate, sane Socialism-a system of government which, while giving individualism fair scope, shall tend to equalise the present social inequalities. The political power of the masses will then steadily increase, and provided they be properly educated they may safely be trusted to use their power wisely. And when the informed masses of the different nations are brought together through accredited leaders and are thus enabled to act coördinately, they, realising how much they have to lose and how little to gain by warring against one another, may be expected to insist that international disputes shall be adjusted on lines of justice and common-sense.

Commercial competition constitutes an important cause of warfare; naturally each nation tends to do the best for itself commercially. Hence has arisen the pernicious system of tariffs by which each nation strives to encourage its own industries at the expense of those of other nations, and this artificial bolstering-up of home industries sets artificial boundaries between the nations and is a perennial source of jealousies, frictions, and quarrels. An infinite benefit would be conferred upon the world at large by a removal of these artificial barriers and by the adoption of free trade all round. Not only would this do away with the immense amount of delay and inconvenience necessitated by the collection of duties ; not only would it facilitate international intercourse and liberate armies of officials engaged in unproductive labour for employment profitable to the State, but, most important of all, it would remove what is perhaps the chief cause of warfare.

The establishment of a United States of Europe trading among themselves as do the United States of America, without any harassing restrictions, has surely been the dream of everyone who has thought seriously over the social future of the peoples of Europe. Under such a system each State should as far as possible be constituted with due regard to race, history, and popular vote; each should be allowed to govern itself in its own way without any unwise interruption of historical continuity or any undue breaking away from tradition, and no State should arrogate to itself precedence over any other. The fighting force of each State should be no larger than would suffice for the maintenance of internal order, and all plant for the manufacture of weapons other than those needful for this purpose should be scrapped. There would thus be an end of artillery-light and heavy-quick-firing guns, bombs, mines, and the like. The sole firearm remaining would be the rifle which. being used for sport, could not well be discarded. Needless to say that with these restrictions, aerial and submarine warfare would die a natural death, while warfare by sea and land, if it did occur, would be infinitely less disastrous than at present-though quite as efficacious. (I mas remark by the way that aerial warfare bids fair to eliminate all other forms. What naval or military base could withstand the bombardment of 50,000 aeroplanes? Only subterranean chambers are safe from serious aerial attack.) Any breach of the covenant by a State, or any dispute between one State and another, should be referred to a supreme tribunal constituted of delegates from each State.

I am aware, of course, that at the present time such a scheme is purely visionary : it is but a dream, yet it is one that we may well strive to make a reality.

\section{Postscript.}

Considerations of space have prevented me from dealing with many aspects of my subject. One of these relates to fear. Is it not wonderful that so many millions of men are capable of mustering sufficient courage to face the terrors of modern warfare? Courage is an asset of inestimable value.

Cowards die many times before their deaths;

The valiant never taste of death but once.

We as medical men are familiar with the pathophobiac who pays us periodical visits in order to be assured that there is nothing the matter with him, and of the man who smilingly meets a lingering death from cancer of the larynx. One of the unhappy effects of modern warfare is that it tends to preserve the timid at the expense of the brave, thus lowering the racial level of courage. The brave man seeks out danger, the timid man avoids it, and there are many ways of evading dangerous service and of minimising risks.

The liability to fear may be so great as to be pathological. One of this temperament is apt to become the victim of morbid fears-fears baving no adequate objective cause. Olaustrophobia is such a fear. I am led to refer to it here because the conditions of modern trench warfare are specially calculated to call it forth, and also because $\mathrm{Dr}, \mathrm{W}, \mathrm{H}, \mathbf{R}$. Rivers has recently related an interesting case of this disease in the pages of this journal. ${ }^{1} \mathrm{My}$ interest in claustrophobia was roused many years ago by a family of claustrophobiacs, and since then $I$ have had the opportunity of studying several cases.

Those who display a constitutional morbid tendency to fear-the congenital phobiacs, as we may term themconstitute a definite class of psychasthenics. What particular form their fear, or fears, shall take depends very largely upon chance circumstances, but claustrophobia, like the fear of the dark and other instinctive fears, tends to be inherited as such, as $I$ have several times observed. This morbid fear appears to be an exaggeration of a normal instinct-the dread of capture, or of anything which interferes with bodily freedom. It will be remembered that one of Lear's wicked daughters, in her endeavour to outbid her sisters for the father's goodwill, could think of no more precious possessions than "eyesight, space, and liberty."

In the family referred to the father, several of the children, and some of the grandchildren have displayed well-marked claustrophobic tendencies, and I have satisfied myself that in each case the fear has arisen independently, and that mutual suggestion has played no part in the pathogenesis. One of the sons has not travelled for 30 years in a train ; another son, at the age of 50, suddenly developed panic while travelling in the Tube, and has had to give up that mode of travelling.

I would take this opportunity of advancing two propositions bearing upon the pathogenesis and treatment of psychasthenia.

1. The essential feature of all the phobias met with in psychasthenia, and, indeed, of all forms of genuine psychasthenia, is a congenitally defective mental temperament-an abnormality in the realm of feeling tone. How far this depends upon defective cerebral organisation (e.g., of the paleo-thalamus, the probable centre of feeling tone), or how 
far upon the composition of the blood plasma, need not now be considered.

2. Mental temperament is inborn, and but little susceptible of being altered. A person is born with a certain temperament for which he is no more responsible than for the shape of his nose, and this inborn temperament tends to remain fundamentally the same throughout life, resisting almost completely all attempts, educational or psycho-therapeutical, to modify it. No doubt some of his emotional disposition can be modified by training - an artistic aptitude can be developed by constant exercise, a bad temper bettered by systematic control-yet the native temperament remains, fundamentally unchanged. A person's temperament never in fact, undergoes a decided change except as the result of the normal cyciical changes, such as puberty and senility, or in consequence of disease, such as Graves's disease, myxoedema, or actual insanity. We meet a man we have not seen for years, and when we come to speak to him it is as if we were carrying on a conversation of yesterday, so conscious are we of his unaltered temperament; and it is this which constitutes the essence of the man, or, as we say, his personality. There are the same old gestures, the same old tricks of speech, the same old play of facial expression, all indicative of the same temperament. Contact with the world, his successes, his failures, his troubles, have no doubt left their impress. Youthful ardour may have been damped; the optimist may have lost some of his hopefulness; the shy man may have grown bolder; the genial man may have become somewhat soured, the cheery nature more subdued; but all such changes are on the surface only. When we come to probe below the surface we shall find that the temperament remains fundamentally the same: the very sensitive, the very shy, the very timid, the irrepressibly selfconfident, remain sensitive, shy, timid, self-confident to the end of the chapter.

Now if the foregoing propositions are sound-if a congenitally morbid mental temperament constitutes the basis of classical psychasthenia, and if temperament is all but insusceptible of being changed-the limitations of psychotherapy in psychasthenia are apparent. If we cannot alter feeling tone, strike at the foundation upon which the whole superstructure of psychasthenia is built up, we cannot cure the affection. In my experience the congenital psychasthenic remains psychasthenic to the end. I am far from saying that psychic treatment is wholly useless for these patients. Much can be done to establish a sane habit of thought and to discipline morbid feeling tone, even though this remains essentially the same.

As to the legitimacy of the conclusions Dr. Rivers draws from his case I am somewhat doubtful. His patient, one judges from the description, appears to be a congenital psychasthenic with a bent towards claustrophobia. It is, of course, conceivable that but for the early claustrophobic incident the specific fear of closed spaces would never have displayed itself; but everything must have a beginning, and I judge that the experience with the dog happened to be the first opportunity for the display of the specific fear. Thereafter it showed itself on several occasions, and I suggest that these later manifestations would have occurred even in the absence of the initial incident.

My experience of claustrophobia leads me to doubt whether the mere resuscitation of a forgotten experience is capable of dispersing the fear. May not the cure (?) in Dr. Rivers's case be an instance of faith-healing? Do we sufficiently realise the tremendous power of absolute belief? If we could convince a person that by jumping off the Monument in a particular way he would plane gently down and alight unhurt below, he would have no kind of hesitation in attempting the experiment. Similarly, if we succeed in implanting the belief that the revival of a forgotten fearful experience will for ever prevent the recurrence of a similar fear, we shall go far to prevent its recurrence. The crucial test would be to observe the effect of the revival without letting the patient know that a cure was expected from it.

SOCIETY FOR THE STUDY OF INEBRIETY.-The seventh Norman Kerr lecture will be delivered by Major W. McAdam Eccles, M.S., M.B., F.R.C.S., R.A.M.C. (T.), on Tuesday, Oct. 9th, at 5.30 P.M., in the Robert Barnes Hall, 1, Wimpole-street, Cavendish-square, London, W., on the subject of "War and Alcohol." The honorary secretary of the society is Dr. T. N. Kelynack, 139, Harley-street, W. 1 to whom acceptances of invitations should be addressed.

\section{Uoretapondente.}

\author{
"Audi alteram partem."
}

\section{THE PHYSIOLOGICAL AND ANTISEPTIC PROPERTIES OF FLAVINE.}

\section{To the Editor of THE LANCET.}

SrR,--The tone of Dr. C. H. Browning's letter in your issue of Sept. 15th is an unfortunate one. It seems to be more an expression of his wounded feelings than argument against my findings.

He congratulates himself that in his second paper on flavine, which appeared in the British Medical Journal on July 21 st last, he forestalled me in a number of my experiments. In this matter he may certainly congratulate himself as my article was in the hands of the censorship authorities weeks before his paper appeared. His experiments, however were not carried far enough. In connexion with the toxic power of flavine on the leucocytes, he still used as the maximum time of exposure two hours, which is altogether too short to bring out the full toxic effect on the leucocytes, just as it fails to show the maximum bactericidal power. In his first paper he found that flavine 1 in 500 was the highest dilution which in 20 minutes caused marked inhibition of phagocytosis. In his second paper he states that in two hours flavine 1 in 10,000 had little effect on the phagocytic power. I have found that in five hours flavine 1 in 256,000 gives marked inhibition of phagocytosis, while in 24 hours the leucocytes are completely destroyed by a 1 in $2,000,000$ dilution.

I have shown in my article that a 1 in 2000 dilution of flavine completely inhibits emigration of the leucocytes. However, in a septic wound treated with flavine 1 in 1000 there is still a more or less purulent exudate. This is capable of two explanations: either the in vitro experiment does not represent what happens in the body or the flavine does not come into contact with the leucocytes in the walls of the wound in sufficient strength to prevent their emigration. As we shall see the latter is the more likely explanation.

Experiments cited in my paper show that the purulent discharges from a wound are very potent in "quenching" flavine. The bared surfaces of the wound also have a great affinity for flavine. The following observation illustrates this point. A patient had a cup-shaped wound in the front of his leg following a fracture of the tibia. This depression was about $2 \times 1^{\prime} \times 1 \mathrm{~cm}$. and held about $1 \frac{1}{2}$ c.c. of fluid. It was lined with granulation tissue. The hole was carefully swabbed out and washed with normal saline solution until the washings were elear. In the next two hours it had four changes of flavine (1 in 1000) and then it was filled with flavine (1 in 1000) which was allowed to remain for two hours, after which it was removed. The strength of the flavine removed as measured by the colour intensity was 1 in 3500 . We see, then, that the granulation tissue-walls of this wound extracted in two hours most of the flavine from the solution applied, and that even after they had been well dyed with four changes of 1 in 1000 tlavine during the previous two hours.

The same wound, immediately after I had removed the above-mentioned two-hour sample of flavine, was filled with a fresh supply of flavine 1 in 1000 and left for 15 hours. At the end of that time the walls of the wound were covered with a mucous-like coating which I take to be the same that the distinguished surgeon (name unknown) has commended as "coagulated lymph." On examination this appeared to consist almost entirely of disintegrated leucocytes, a finding quite in keeping with the test-tube experiments on the powerful leucocidal action of flavine.

The original instructions sent out with flavine by the Medical Research Committee, and presumably drawn up by Dr. Browning, stated that it might be employed in conjunction with any of the various techniques recently advocated in wound treatment. In his second paper on flavine Dr. Browning mentions that unsatisfactory results have followed the two-hourly flushing with flavine after the method of Carrel, and he recommends that it be applied on gauze and only the minimum of water should be introduced so that 